\title{
ПОЛІТКОРЕКТНІСТЬ У СУЧАСНОМУ МОВНОМУ ПРОСТОРІ
}

\author{
Колядич Ю. В., Хоцянівська І. В.
}

\section{ВСТУП}

Вивчення співвідношення мови й культури $є$ однією 3 актуальних проблем сучасного мовознавства, бо мова $\epsilon$ дзеркалом культури, у якому знаходять своє відображення суспільна самосвідомість народу, його менталітет, національний характер, спосіб життя, традиції, звичаї, мораль, система цінностей та світобачення. Сучасна глобалізована культура, як відомо, грунтується на таких демократичних цінностях, як вибір, право на власну думку, свобода совісті, а тому зумовила появу культурного й мовного феномену політичної коректності, яке стало невід'ємною частиною міжнародної лінгвокультури i неминуче позначилось на розбудові суспільних відносин.

Саме 3 цих причин у сучасній лінгвістиці, соціолінгвістиці помітною $є$ увага до питань прагматичного характеру, зокрема впливу мови на суспільство. Серед перших спроб описати й дослідити появу політкоректної лексики заслуговують на увагу праці 3.С. Трофімової, С.Г. Тер-Минасової, І.М. Некрасової, Н.Г. Комлєва, Є.В. Шляхтіної. Політкоректну лексику досліджували здебільшого на матеріалі англійської мови в порівнянні 3 російською та українською. Явища політкоректності сьогодні досліджують не тільки в лінгвістичному аспекті, але й у соціальному й культурологічному. Цим питанням присвячено студії вітчизняних та зарубіжних учених О.I. Бондаренка, М.Ю. Палажченко, К.С. Шарова, А.І. Колаковської, У.О. Еко, Л.Г. Іоніна, Е.А. Похолкової та ін.

В останні десятиліття проблема політкоректності, іï основні аспекти були широко представлені в працях лінгвістів, політологів, філософів, соціологів, психологів, культурологів. Зокрема, політкоректність стала предметом дослідження зарубіжних учених Д. Адлера, Д. Д'Соуза, Д. Равича та ін. Прикметною рисою більшості публікацій зазначених американських авторів $\epsilon$ інтерпретація політичної коректності як одного з елементів освітньої доктрини США, а власне мовний аспект цього питання залишається поза увагою.

Отже, посилена увага до дотримання певних норм під час комунікації між представниками різних соціальних прошарків і національностей, віросповідань та інших груп зумовлює актуальність нашого дослідження. 
Мета дослідження - розглянути поняття політкоректності як соціолінгвістичної категорії, з'ясувати причини виникнення цього явища, функціонування у сучасному мовному просторі та мовні засоби вираження.

\section{1. Соціокультурні передумови виникнення політкоректної лексики}

Питання суспільної толерантності стає особливо актуальним у складні перехідні історичні періоди, коли відбувається переоцінка традиційної системи цінностей, зазнають трансформацій певні соціокультурні норми. Час, у який ми живемо, - це одна 3 перехідних епох в історії культури, коли перед людством гостро постають питання про необхідність подолання агресії, нетерпимості, насильства. А тому дослідження ціннісно-смислового навантаження поняття толерантності, його структурних та змістових елементів нині набуває особливого значення, оскільки аксіологічний підхід до цієї проблеми є основою утвердження толерантності як суспільної й індивідуальної цінності та соціокультурної норми.

3 60-х років минулого століття точаться дискусії навколо цієї проблеми. Що включає в себе поняття «толерантність»? Як воно співвідноситься 3 поняттям «терпимість»? Де пролягають межі толерантності? Нарешті, що таке політкоректність, політкоректна лексика, яка іноді сприймається як карикатура на істинну толерантність?

Як відомо, в суспільно-політичній думці та науковій літературі існують протилежні оцінки феномену політичної коректності. Її противники розглядають це явище як замах на традиційні ліберальні цінності, зокрема свободу слова. Критика політкоректності має різні форми (від іронічного висміювання до категоричного неприйняття самої ідеї). Політкоректність навіть оголошують найбільшою інтелектуальною загрозою XXI століття, котра підриває світоглядні основи американського суспільства та всієї західної цивілізації. Прихильники ж політкоректності вбачають у ній інструмент попередження й пом'якшення гострих соціальних конфліктів, підвищення політичної й правової культури суспільства.

Політкоректність, зокрема іï доктрина, визрівала у 1990-ті роки в університетському середовищі США під впливом ідей лібералізму. Визначаючи у своєму виданому 2006 р. «Словнику іноземних слів» поняття політкоректності, російський дослідник Н. Комлев писав: «Політкоректність - поняття-гасло, яке утвердилось у США і яке демонструє ліберальну спрямованість сучасної американської 
політики» ${ }^{1}$. Учений вважає, що це свого роду ідеологічний ерзац, поява якого зумовлена крахом рівноваги ідейно-політичних систем в кінці 90-х років XX ст., який, будучи позбавленим глибокого змісту, є радше символічним образом та коригуванням мовного коду. Можна побачити в політкоректності і явище, пов'язане з притаманною США ситуацією cultural diversity (культурної багатоманітності) та засадами політики мультикультуралізму.

Доктрина політкоректності відштовхувалась від поняття "neutral language" - «нейтральна мова». Саме така мова, звільнена від виразів, котрі ображають почуття та гідність особи, порушують іï людські права, має протистояти мові ворожнечі - hate speech. Мова виключення, репресії, ворожнечі має бути сама виключена із вжитку. Ïї використання не означає бажання уникати незручних тем, навпаки, воно означає бажання говорити про ці теми по-іншому. Встановлення й утвердження в суспільній свідомості спеціальних норм мовного етикету, як вважали прихильники доктрини політкоректності, допоможе створити єдиний комунікативний простір і програмувати толерантну поведінку всіх учасників комунікації.

Дослідниця феномену політкоректності С. Тер-Минасова переконана, що «підходи до вивчення цього феномену $\epsilon$ різновекторними. Це політична коректність як особлива ідеологічна реальність, як мовна зміна, як культурно-лінгвістична тенденція, як мовна толерантність тощо» ${ }^{2}$.

На думку науковців, «поява політичної коректності пов'язана з виникненням ідеї культурного плюралізму i необхідністю пропорційно представити твори літератури і мистецтва, досягнення суспільного i політичного життя, які належать представникам усіх етнічних і сексуальних меншин» ${ }^{3}$.

Отже, політкоректність - явище, у якому домінантну роль відіграє мовний та культурно-поведінковий аспект.

Мовний аспект політичної коректності виявляється в пошуку нових засобів для мовного виразу та коригуванні мовного коду.

Так, у США було вироблено свого роду speech codes - мовний кодекс, який має на меті боротьбу з проявами дискримінації в різних сферах. Деякі дослідники рекомендують вживати слово low-income (малооплачуваний) замість poor (бідняк, злидар), щоб виключити дискримінацію за соціальним статусом, sexworker (працівниця сфери

${ }^{1}$ Комлев Н. Словарь иностранных слов. Москва : Эксмо, 2006. С. 279-280.

${ }^{2}$ Тер-Минасова С. Язык и межкультурная коммуникация. Москва : Слово, 2000. C. 245 .

3 Трофимова 3. Словарь новых слов и значений в английском языке. Москва : Павлин, 1993. С. 227. 
сексуальних послуг) замість образливої назви однієї з найдавніших професій - prostitute. Боротьба з сексизмом виявляється у відмові користуватись зверненням Mrs. (Micic) i Miss (Mic), замінюючи ïx нейтральним по відношенню до сімейного статусу Ms (Мiз). У багатьох назвах професій, які мають компонент man, котрий, за твердженням філологів, у первісному значенні перекладається не як у сучасній англійській мові - «чоловік», а як «людина», замінюють цей компонент на person: chairman - chairperson, congressman - congressperson. Словник політкоректної мови включає евфемізми, спрямовані проти дискримінації за віком (golden ager - «особа золотого віку»- замість «старий») та за зовнішнім виглядом (hair disadvantaged - «позбавлений волосся»-замість «голомозий») ${ }^{4}$.

Проблемі speech codes присвячено книгу експерта в галузі освіти, професора Нью-Йоркського університету Дайан Равич «Поліція мови: як групи впливу обмежують навчання студентів» 5 . Книга включає 500 слів та виразів, які ніколи не трапляються в американських шкільних та університетських підручниках. У наведеному авторкою списку, крім інших, $\epsilon$ слова «Бог», «пекло», «сліпий», «старий», «варвар», «домогосподарка», які відповідною комісією були віднесені до необ'єктивних та упереджених, оскільки вони можуть образити почуття деяких груп. «Новояз Джорджа Орвела стає реальністю», коментує політику політкоректності Д. Равич. Дослідниця має на увазі роман-антиутопію відомого англійського письменника «1984», де замальовується тоталітарне майбутнє Європи, одним 3 елементів котрого $€$ новояз (Newspeak) - вихолощена мова, котра повинна зробити неможливим опозиційний спосіб думок («мислезлочин»).

«Як можна визначити політкоректність у двох словах? - пише К. Шаров, автор однієї з статей, присвячених цій проблемі. - Це певний новояз - мова Езопів наших днів, які схильні перейменовувати всі речі та явища. Для чого? Щоб не вважатись негідником, який зневажає або обмежує чиїсь права. Раса, етнос, стать, віросповідання, сексуальна орієнтація, політичні погляди, вік, інтелектуальні здібності, фізична конституція, психотип, характер, темперамент індивіда та інші його атрибути залучені у сферу панування політкоректності» ${ }^{6}$.

${ }^{4}$ Панин В. Политическая корректность как культурно-поведенческая и языковая категория : автореф. дис. ... канд. филол. наук : 10.02.20 «Сравнительноисторическое, типологическое и сопоставительное языкознание». Тюмень, 2004. C. $14-15$.

5 Ravitch D. Multiculturalism: E Pluribus Plures. Are You Politically Correct?: Debating America's Cultural Standards. Prometheus Books, Buffalo, NY, 1993. P. 170.

6 Шаров К. На темной стороне политкорректности: гендернонейтральный новояз. Вопросы философии. 2010. № 3. С. 34. 
Критики політкоректності справедливо дорікають іï прихильникам саме за схильність до мовної еквілібристики замість конкретних дій, спрямованих на розв'язання реально існуючих проблем. Про цю обмеженість політкоректності говорить, зокрема, У. Еко, який вважає, що замість удосконалення суспільства доктрина політкоректності пропонує удосконалювати лексику. «Коли суспільство починає називати неходячих не «інвалідами», а «альтернативно розвинутими» (diversamente abili) замість того, щоб будувати для них пандуси, зрозуміло одне: лицемірно розправившись 3 попереднім терміном, провели косметичний ремонт у мові, але не ремонт сходів» ${ }^{7},-$ пише філософ. Учений справедливо зазначає, що політкоректність покликана насаджувати толерантність, а це перетворює ії на новітню форму фундаменталізму, який канонізує букву, нехтуючи духом самої доктрини. У певному сенсі політкоректність починає протистояти толерантності, оскільки передбачає нетолерантне ставлення до тих, хто не підтримує іiі ідеологію та практику. Продовжуючи цю думку, У. Еко стверджує, що через політкоректність глобалізована культура потрапила в ситуацію, котру в Штатах прийнято називати zugzwang (цугцванг): не ходити не можна, а кожен хід лише погіршує становище гравця.

Вчені переконані, що політкоректність небезпечна своєю одномірністю. Вона ставить за мету формування безстатевої істоти універсальної ідентичності, яка не лише позбавляється права на публічний та відвертий діалог, а навіть бажання такого діалогу. Політкоректний новояз дозволяє структурувати та регламентувати інформаційний простір і подачу інформації, тобто відсікати від поширення політично неблагонадійні теми та формувати суспільну думку у «вірному напрямі». Політкоректність - це заздалегідь задане ідеологічне обмеження погляду на світ. Як завжди у таких випадках, картина світу виявляється дещо деформованою.

О. Сінькевич зауважує, що «противники та критики політичної коректності називають іï багатоголовим чудовиськом та терором доброчесності, сучасною інквізицією, яка вишукує політично некоректну єресь і влаштовує єретикам аутодафе у вигляді переслідувань, кампаній по

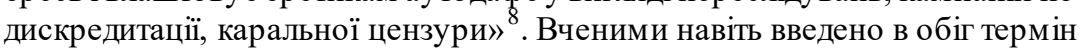
«репресивна толерантність». За твердженням дослідників, він відображає готовність системи не просто терпіти, а навіть заохочувати різноманітну опозиційність та маргінальність, допоки ця опозиційність, дозволяючи

7 Эко У. О политкорректности. Полный назад / пер. с итал. Москва : Эксмо, 2007. C. 169.

8 Сінькевич О. Політкоректність в контексті глобалізаційних процесів сучасності. SWorld. 2013. №2. C. 7. 
уявні альтернативи, не порушує правилгри, встановленихСистемою, та не загрожує іiі існуванню.

Ідеологію та практику політкоректності піддає гострій критиці польський філософ, філолог, перекладач А. Колаковська. У своєму есеї «Imagine: Інтелектуальні витоки політкоректності», досліджуючи генезу цієї доктрини, дослідниця вбачає ії в утопії американського руху гіпі - «дітей-квітів» 60-х років та філософії «Нью-ейдж».

На думку дослідників, політкоректність $є$ лівою антиелітарною ідеологією, яка ворожа культурі та цінностям Заходу. Вона $\epsilon$ нетерпимою, хоча й проголошує терпимість, тоталітарною, оскільки намагається підпорядкувати своӥм вимогам мислення у всіх сферах життя. Вона спирається на абстракті принципи, які заперечують здоровий глузд, розділяе суспільство на групи, котрі живуть своїми відокремленими інтересами. Вона проголошує своєю метою справедливість і благо людини і зневажає людей, факти та розум. Вона вимагає максимального втручання держави в життя і бажає кожну сферу регулювати на законодавчому рівні.

Окремі дослідження, присвячені політичній коректності, позначені критикою надмірного патерналізму ідеології політкоректності стосовно меншин, які можуть мати власну позицію, що не завжди збігається 3 позицією тих, хто виявляє стосовно них «батьківську турботу». Так, російський соціолог, політолог, філософ Л. Іонін вважає, що політкоректність перетворює сучасне суспільство на «суспільство меншин». На його думку, політкоректність породжує новий тип соціальної структури, де базовими та груповими ідентифікаціями $є$ категорії різного роду меншин, які колись піддавались або нині піддаються дискримінації 3 боку панівної більшості. Ця панівна більшість кожного разу визначається по-іншому залежно від характеру меншини. По відношенню до жінок такою більшістю $є$ чоловіки, до чорних - білі, до огрядних - стрункі, до потворних - красені, до дурних - розумники. Як наслідок суспільство перетворюється на суспільство меншин, в якому лише меншини видаються реально існуючими 9 .

У своій книзі «Політкоректність: Дивовижний новий світ» Л. Іонін висловлює думку про те, що «політкоректність виростає з постмодерну, котрий урівнює в правах всі концепції та погляди, приймає будь-яку позицію, ідеологію, поєднуючи їх в нескінченну різноманітність колажів. Усе дозволено i все прийнятно, i, щоб не виглядати

9 Ионин Л. Общество меньшинств: политкорректность в современном мире. Москва : Издательский дом Государственного университета, 2010. С. 21. 
вигнанцем, людина погоджується 3 тим, що визнає більшість» ${ }^{10}$. Чимало дослідників сам термін «політкоректність» часто називає невдалим, але згадаємо, що друга його частина - «коректність» походить від латинського correctus - ввічливість, тактовність, поштивість, чіткість, точність. Отже, коректність - одна з базових засад етикету, культури поведінки. О. Сінькевич стверджує, що «мовний етикет містить ряд загальноприйнятих правил, які порушують лише ті, хто не може похвалитись гарними манерами. Вибирати вирази - це стандарт поведінкової культури, випробуваний століттями, вираз незаперечної істини про єдність змісту і форми ${ }^{11}$.

Як відомо, політкоректна поведінка говорить про людину більше, ніж нічим не підкріплена декларація про погляди та наміри.

Дехто називає політкоректність виявом лицемірства, небажанням називати речі своїми іменами, чимось неприродним для людини, яка наділена агресивними інстинктами. Культурологи переконані, що по відношенню до норм культури поняття «природне» та «неприродне» слід вживати обережно: ватерклозет, наприклад, - річ неприродна, адже тварина ним не користується, однак це не означає, що ним не повинна користуватись людина. Крім того, політкоректність делегітимізує «природну» агресію, забороняє надавати «природній» ксенофобії статусу ідеології, яка закликає до відповідної дії.

Політкоректність, реалізована в повсякденному житті, сприяє дружнім стосункам, миру та злагоді. Учений Г. Нікифорович у статті «Політична коректність як точна наука» пише, що запровадження політкоректності у США - безсумнівне благо, оскільки вона допомогла суттєво знизити рівень ксенофобії в американському суспільстві. Старожили провінційного містечка Сент-Луїса розповідають, як півстоліття тому навіть найбільш ліберально налаштовані білі не запросили б до себе негра, адже вони не відважились би наражатись на засуджуючі погляди сусідів. Нині, навпаки, осуду буде підданий той, хто відмовляється приймати у своєму домі людей іншої раси. «Це прямий результат політкоректності, хай не завжди щирої, але набагато привабливішої, ніж щира ксенофобія» ${ }^{12},-$ вважає дослідник.

Очевидною $є$ думка про те, що політкоректність стимулює процес демократизації суспільства, сприяє утвердженню почуття гідності людини, демонструє повагу до індивіда. Вона є соціально-політичним

10 Ионин Л. Политкорректность: Дивный новый мир. Москва : ООО «Ад Маргинем Пресс», 2012. С. 95.

11 Сінькевич О. Політкоректність в контексті глобалізаційних процесів сучасності. SWorld. 2013. № 2. С. 8.

12 Никифорович Г. Политическая корректность как точная наука. URL: http:/magazines.russ.ru/zz/19/ni17.html. 
самообмеженням, котре слугує інструментом накопичення цивілізованості, навчання тому, що люди мають бути терпимими по відношенню до представників іншої раси, статі, релігійних переконань $^{13}$.

Справжня толерантність передбачає як повагу до цінностей та смислів, важливих для іншого, так і усвідомлення та прийняття власного внутрішнього світу, власних цінностей та смислів, цілей ібажань, переживань та почуттів. Людина повинна мати межі в розумінні та прийнятті світогляду інших людей, адже це дає ій можливість не боятись можливих суперечностей та конфліктів, які також є невід'ємною складовою частиною людського буття. Отже, дотримуючись правил та норм політкоректності, необхідно демонструвати зрілість і самостійність, без якої неможлива істинна толерантність.

\section{2. Політична коректність як соціолінгвістичне явище}

Поняття політкоректності як ідейна течія виникло в останні роки минулого століття на Заході, але найяскравіше виявило себе в США, ставши своєрідною відповіддю на расові, гендерні, соціальні, екологічні та інші проблеми, що хвилюють не тільки американське суспільство, а й усе сучасне людство. Політкоректність є специфічною для культури й мовної практики США, проте відображає вплив і на інші мови, зокрема на східні. У 1990-ті роки переважно в університетському середовищі США термін знаходить своє цілком сучасне значення того, що англійською також виражається поняттями "inclusive" або "neutrallanguage" - концепції, що базується на гіпотезі Сепіра-Уорфа (en: Sapir-Whorf hypothesis), яка постулює, що лінгвістичні категорії формують поняття i дії мовця. Політична коректність, як зауважують дослідники, передбачає заміну слів, які мають статеву приналежність, на гендерно нейтральні терміни, наприклад, «chairperson» замість «chairman» (голова), використання piзних форм iз «challenged» («людина 3 особливими потребами», або «той, хто змушений долати труднощі») замість тих, які використовувалися раніше, простих слів для людей із фізичними вадами («сліпий», «кульгавий», «інвалід»). Бажання дотримати політкоректності у релігійній площині призвело до того, що в деяких англомовних країнах традиційне побажання «Merry Christmas» («веселого Різдва») стали часто замінювати на «Нарpy Holidays»

13 Лобанова Л. Новый стиль речи и культура поколения. URL: www.portalslovo.ru/philology/374Л21.php. 
(«щасливих свят») у випадках, коли воно звернене до людей невідомого віросповідання (наприклад, до широкого загалу).

В останні 10-15 років поняття політкоректності поступово стало поширюватися й на сексуальні меншини. Політкоректність стосовно них припускає неприйнятність закликів до будь-якої дискримінації чи обмеження прав або до переслідування представників сексуальних меншин, а також тих, що пропагують нетерпимість до сексуальних меншин, гомофобію, гетеросексизм (гетеросексуальний шовінізм), а також неприпустимість вживання по відношенню до сексуальних меншин образливих для них найменувань ${ }^{14}$. Коректного позначення для транссексуалів набули MtF i FtM. Плутанина в ЗMI з тим, як називати транссексуалів (він / вона, колишній чоловік, колишня жінка) викликане нерозумінням суті цього явища. Як і раніше, вважається некоректним вислів «змінити стать», його замінено на «корекція статі». Деякі вважають слово «woman» нерівноправним слову «таn». Останнє раніше означало «людина», але було монополізовано як назва чоловіка. Замість «woman» використовують «female» і слова, повернуті з давньої англійської. Політкоректність полягає у тому, щоб у мовному вжитку уникати всього того, що могло б бути образливим для тих чи тих категорій осіб за ознакою раси, статі, віросповідання, сексуальної орієнтації, віку, інтелектуальних здібностей і т. д., уникаючи (в ідеалі) осмисленого висловлювання взагалі (назвати злодія злодієм неполіткоректно). На думку низки авторів, в англомовних країнах термін вживається майже незмінно з іронією чи несхваленням.

Як відомо, американський варіант англійської мови дуже відомий своєю політкоректністю, яка активно просувається в публіцистичному, політичному, освітянському та й побутовому дискурсі. Відповідне явище $\epsilon$ наслідком боротьби з дискримінацією за статевими, расовими, етнічними та іншими ознаками. Однак як наслідок утворені неологізми $\epsilon$ більш курйозними, ніж тактовними. Слід розуміти, що політкоректність - це не просто новий синонім для таких понять, як ввічливість чи толерантність. Політкоректність - це певна політика, певний спосіб поведінки. Особливостями політкоректності $є$ іï крайня запобігливість, адже засуджуються не просто образливі вчинки, а усе, що потенційно може бути образливим. У разі оцінки мотивації вчинку чи слів, які можуть розглядатися як образливі, обирається, як правило, варіант інтерпретації, максимально близький до зумисного вчинку. Також для політкоректності характерна крайня неконфліктність. Тобто,

14 Палажченко М. К вопросу о политической корректности, настоящей и мнимой, и политике двойных стандартов. Вестник МГУ. Сер. 19. «Лингвистика и межкультурная коммуникация». 2004. № 1. С. 82. 
якщо виникає вибір між кількома варіантами інтерпретації події, факту, вчинку, обирається найменш образливий, навіть якщо він $є$ менш імовірним чи навіть відверто надуманим. Ще однією особливістю практики політкоректності $€$ неоднаковість підходу. Оскільки сучасна політкоректність виросла 3 руху за права меншин, переважно одні групи розглядаються як жертви, а інші як агресори ${ }^{15}$. Сама політкоректність застосовується майже виключно щодо дій «агресорів» стосовно «жертви». Згідно 3 принципами політкоректності в суспільстві не повинно існувати упереджень у ставленні до людей нетрадиційної сексуальної орієнтації. Питання дотримання їх прав $\epsilon$ об'єктом пильного контролю з боку громадськості й обговорюються на найвищому державному рівні. У зарубіжному науковому дискурсі, зокрема в словниках, підходи до визначення політкоректності різні. Проте здебільшого це поняття означає необхідність поводитися ввічливо, дотримуючись правил i норм поведінки, прийнятих в суспільстві.

Автори соціологічного словника-довідника «Социология: А - Я: словарь-справочник» Г. Лоусон i Д. Гэррод пропонують таку дефініцію: «Політична коректність (political correctness) - в очах іï опонентів швидше міфічне, ніж реальне, явище, яке полягає в прагненні виключити будь-який прояв дискримінації людей за ознакою статі, етнічної приналежності, фізичних здібностей або сексуальної орієнтації» ${ }^{16}$. «Карманная энциклопедия The Hutchinson» Helicon Publishing Ltd (EN) містить таке визначення: «Політична коректність розмовний термін, що використовується для визначення ліберального ставлення до проблем освіти й суспільного статусу й всього, що з цим пов'язане» ${ }^{17}$. Щоб бути політично коректним, потрібно реагувати на прояви расизму, сексуального насильства, проявляти турботу до навколишнього середовища.

Питанням походження терміна «політична коректність», його історією, виникненням евфемізмів у російській, українській та англійській мовах цікавились зарубіжні та вітчизняні дослідники К. Аллан, А. Асмолов, Г. Солдатова, Л. Городецька, Л. Крисін, М. Лапшина, В. Маслова та ін. Дослідники наполягають на тому, що політкоректність спрямована на те, щоб знайти нові способи мовного вираження замість тих, які торкаються почуттів та гідності окремої

15 Шляхтина Е. Языковой аспект политкорректности в англоязычной и русской культурах : автореф. дис. ... канд. филол. наук : 10.02.19 «Теория языка». Ярославль, 2009. С. 13.

${ }^{16}$ Карманная энциклопедия The Hutchinson. Москва : Внешсигма, 1995. С. 355.

17 Там само. С. 356. 
людини, для якої $є$ звичною мовна безтактність чи прямолінійність стосовно раси, статі, віку, стану здоров'я, соціального статусу, зовнішнього вигляду та ін. Л. Цурикова дає характеристику політкоректності не тільки у форматі мовного, але й соціальноповедінкового аспекту. В. Реймонт стверджує, що «під політичною коректністю треба розуміти ідеологічно-політичний рух 1980-х 1990 pр. США, поширений ліберальними групами, які виступали за дотримання норм нейтральної мови щодо статі, віку та ін.» ${ }^{18}$. На думку С. Тер-Минасової, у російської мовній культурі політкоректна лексика використовується помірно. Вона $є$ характерною більше для західноєвропейських мов, що можна пояснити високою соціальною й поведінковою культурою, менталітетом та ідеологією культури.

У 1970-х роках на вимогу феміністичних спільнот і за активної участі їхніх представників відбулася гендерна мовна реформа. Вона була спрямована на позбавлення англійської мови ознак вербальної дискримінації за ознакою статі. Тоді ж виникло поняття «сексизм», тобто дискримінація групи людей через їхню гендерну приналежність ${ }^{19}$. Традиційними аргументами, які, на думку феміністок, призводять до сексизму, є посилання на обмеженість жінок у здатності до навчання, згадування так званої жіночої логіки та психічної нестабільності, що ставить жінку на нижчий щабель у суспільстві. Ці аргументи поширилися у суспільстві через ЗМІ. Але попри те, що явище політкоректності своєю метою мало покращити мову, позбавити ii образливих фраз та слів, виникла велика кількість штучних номінативів, які, на думку багатьох лінгвістів, лише псують мову. До найпоширеніших видів дискримінації в українському суспільстві належать статева, расова і за належністю до сексуальних меншин.

Згідно 3 рекомендаціями Школи журналістики та зв'язків згромадськістю під час висвітлення гендерних питань необхідно дотримуватися підходу, заснованого на принципі рівності, який базується на таких принципах:

- дотримання балансу в описах жінок та чоловіків. Якщо в повідомленні ідеться про жінку, то описувати іiі необхідно, як і чоловіка. Наприклад, якщо журналіст у сюжеті не описує зовнішній вигляд чоловіка, то робити це щодо жінки буде некоректно;

- виважене вживання лексики при описі зовнішності;

18 Raymond W. Dictionary of Politics. Brunswick Publishing Co., Lawrenceville, Virginia, 1995. C. 286.

${ }_{19}$ Kołakowska A. Imagine: Intelektualne źródła poprawności politycznej. Wojny kultur i inne wojny. Warszawa : Fundacja Swietego Mikolaja, 2012. P. 212. 
- вживання нейтральних слів, що не відображають перевагу певного гендеру над іншим;

- уникнення слів чи виразів, що містять гендерні упередження ${ }^{20}$.

Починаючи 3 70-х років $\mathrm{XX}$ століття, лінгвісти розмежовують поняття «стать» і «гендер». Стать - це біологічні характеристики, які розрізняють чоловіка й жінку, а гендер - це соціальний конструкт. На цьому підгрунті навіть виникла окрема наука - гендерна теорія, яка нещадно критикує гендерні стереотипи й обгрунтовує необхідність їх долати. Ці стереотипи підтримують гендерну поляризацію твердження, що люди різної статі діаметрально протилежні. Звісно, між чоловіками й жінками $\epsilon$ розбіжності, що доводять численні дослідження у площині соціології та психології, проте ці дослідження також вказують і на значні спільні характеристики осіб обох статей. Однак факти, що стверджують подібність, залишаються в тіні, у той час як на загальне обговорення потрапляють саме відмінності, та ще й значно перебільшені, що й породжує гендерні стереотипи. Через ідею відмінності утверджується в суспільній свідомості гендерна нерівність, яка здавна існує в різних етнокультурних спільнотах ${ }^{21}$.

Як пише Н.В. Собецька, в українській мові фемінітиви сьогодні становлять досить широку і багатогранну підсистему слів 3 належною термінологічною базою, відповідним статусом самостійних лексичних одиниць, великою кількістю лексичних підгруп, різними стилістичними ознаками, семантичними відношеннями між собою, усталеною словотвірною базою й власними способами деривації ${ }^{22}$.

Олена Малахова зазначає, що найпродуктивнішими суфіксами для творення фемінітивів в українській мові $\epsilon$ суфікси -к- (учителька, директорка, лідерка), -иц- (урядовиця, авантюрниця, очільниця), -ин(філологиня, філософиня, своякиня), -ес- (агентеса, адвокатеса, критикеса), меншою мірою-ис- (актриса, редактриса) $)^{23}$.

У живій українській мові активно використовують назви низькокваліфікованих чи низькооплачуваних професій в жіночому роді (прибиральниця, кухарка, домогосподарка, покоївка, манікюрниця, офіціантка), а такі назви чоловічого роду, як професор, ректор, науковець, на думку супротивників фемінітивів, звучать авторитетніше i без емоційних конотацій. Однак іноді нові фемінітиви навмисно

${ }^{20}$ Бондаренко О., Буткевич М. Мова ворожнечі та 3МІ: міжнародні стандарти та підходи. Київ : Проєкт «Без Кордонів» ГО «Центр «Соціальна Дія», 2015. С. 14.

${ }^{21}$ Маєрчик М., Малес Л. Гендер для медій. Київ : Критика, 2017. С. 122.

${ }^{22}$ Собецька Н. Вживання фемінітивів як прояв гендерної культури. Молодий вчений. Т ернопіль : Тернопільський національний економічний університет, 2016. С. 376.

23 Керст I. Олена Малахова: «Фемінітиви - не данина моді, вони властиві українській мові як системі». WOMO. 2018. URL: http://womo.ua/olena-malahova/. 
маркуються стилістично. Такі слова, як депутатка, керівниця, можуть вживатись, щоб виразити жартівливо-іронічний відтінок або підкреслити негативне ставлення до жінки ${ }^{24}$.

Олена Малахова вважає, що, попри поширену думку, що фемінітиви - це данина моді, ці одиниці мають давню традицію, а в архівних текстах до 30-х років минулого століття можна часто натрапити на них навіть в офіційних текстах ${ }^{25}$. До того ж дослідниця стверджує, що вживання фемінітивів закономірне, адже вони властиві українській мові як системі.

На нашу думку, репрезентація жінки у ЗМІ повинна відповідати сучасним стандартам гендерної рівності, а фемінітиви мають потенціал стати невід'ємним фактором боротьби 3 гендерними стереотипами і можливістю гідно відображати роль жінки в суспільстві.

Темношкіре населення США було обурене ставленням до них, зокрема вживанням слова black, що, на їхню думку, звучало образливо. Вони вимагали дерасилізації англійської мови, вказуючи на різницю між вживанням слів black, white, тому що друге слово містило в собі позитивне конотативне значення. Це $\epsilon$ очевидним у наведених прикладах: black sheep, black market, blackmail, а також white dove, white lie, white man. 3 тих пір вживання слів 3 негативною конотацією стосовно темношкірого населення перетворилося на гостру проблему, яка $\mathrm{i}$ сьогодні до кінця не вирішена, що й призвело до змін в англійській мові.

У американській пресі 30-х - початку 60-х рр. минулого століття при позначенні чорних американців уживалося переважно слово Negro iз великої літери. Варто зазначити, що тоді етнонім Negro не викликав таких негативних асоціацій, як сьогодні. У статті “The Law In Two Colors” (1955) 3 газети "The Christian Science Monitor" порушено проблему нерівноправного становища негритянського населення в одному 3 південних штатів. Автор виражає обурення існуванням пережитків расової дискримінації, на які влада фактично заплющує очі. У даному контексті Negro позбавлене негативних конотацій іє радше нейтральним:

Two shameful instances of mistreatment of Negroes have been reported from Live Oak by Tribune Staff Write Sam Mase. These cases lead to the conclusion that in Suwannee County the law operates one way for Negroes

24 Собецька Н. Вживання фемінітивів як прояв гендерної культури. Молодий вчений. Тернопіль : Тернопільський національний економічний університет, 2016. C. 377.

25 Керст I. Олена Малахова: «Фемінітиви - не данина моді, вони властиві українській мові як системі». WOMO. 2018. URL: http://womo.ua/olena-malahova/. 
and another way for whites ("The Christian Science Monitor", Saturday, September 3, 1955).

Як відомо, ЗМІ несуть відповідальність за правдиве, справедливе, вільне від стереотипів та упереджень зображення людей з інвалідністю. Експерти погоджуються, що мова та слова, що використовуються для позначення людей 3 інвалідністю, мають прямий вплив на те, як суспільство їх сприймає і як до них ставиться. Використання мови, що підкреслює особу, а не ii інвалідність, допомагає боротися із некоректністю та сприяє покращенню інклюзивності в суспільстві.

Розуміння стереотипів про людей 3 інвалідністю допомагає їх уникнути та створити конструктивний образ в медіа, а також запропонувати конструктивний образ на основі реальності.

Зазвичай стереотипи пов'язують людей 3 інвалідністю 3 хибними образами жертви та супергероя. В образі жертви людина постає як вразлива, стражденна, недієздатна і безпорадна, в образі супергероя як взірець для натхнення, що «наперекір своїй інвалідності» виконує щоденні рутинні справи або навіть досягає певних висот, наприклад, у сфері спорту, науки, музики тощо. Розповідаючи про людей 3 інвалідністю в ЗМІ, потрібно пам'ятати, що мова йде про людину, про особистість, а не про ії інвалідність.

В Україні 16 січня 2018 року офіційно заборонили термін «інвалід». Лариса Байда 3 Національної асамблеї людей 3 інвалідністю пояснює, що коректно вживати одиниці «людина 3 інвалідністю», «людина 3 аутизмом», «людина 3 контузією», адже тут увага акцентується на особистості, а не на іiі стані здоров'я. Прийнятними також $\epsilon$ терміни «люди 3 інтелектуальними порушеннями» та «люди 3 психічними порушеннями», «незрячі люди», «нечуючі люди», «люди, які отримали каліцтва», «люди 3 ампутацією» ${ }^{26}$.

Необхідно відмовитися від часто вживаних термінів «людина з обмеженими можливостями», «неповносправна особа», «людина з особливими потребами», «особливі діти», «прикутий до візка», «каліка», «людина, що страждає на ДЦП» ${ }^{27}$.

У статтях про людей 3 інвалідністю українські 3МІ здебільшого використовують таку нейтральну термінологію: «людина 3 інвалідністю», «особа 3 інвалідністю», «людина 3 вадами слуху», «людина 3 розумовими порушеннями», «незрячий», «людина з вадами

26 Андрейців I. Словничок освіченого українця. Як можна і не можна говорити про людей. Українська правда. 2018. URL: https://life.pravda.com.ua/society/ 2018/01/23/228588/.

27 Андрейців I. Словничок освіченого українця. Як можна і не можна говорити про людей. Українська правда. 2018. URL: https://ife.pravda.com.ua/society/ 2018/01/23/228588/ 
зору». Однак журналісти досі послуговуються термінами «людина з обмеженими можливостями», «людина 3 особливими потребами», «особливі діти», які можуть здатися толерантними порівняно з грубим словом «інвалід», але вже $\epsilon$ застарілими й стають на заваді забезпеченню інклюзивності в медіа.

\section{ВИСНОВКИ}

Отже, політична коректність у своєму сучасному значенні зародилася в Сполучених Штатах Америки на початку 80-х рр. минулого століття. Основною причиною поширення політичної коректності в США стали такі чинники:

a) мультинаціональність американського суспільства, що зумовила потребу враховувати інтереси всіх етнічних груп, що населяють США, особливо таких, як афроамериканці, латиноамериканці та індіанці;

б) активність феміністських спільнот та організацій, котрі захищають права національних, сексуальних меншин, інвалідів, груп, що борються за збереження навколишнього середовища і права тварин.

3 часом поняття «політична коректність» значно поглибилося і набуло статусу культурно-поведінкових і мовних норм, усталених в суспільстві, які спрямовані на знищення дискримінації за національною чи расовою ознакою, сексуальною орієнтацією, статевою приналежністю, станом здоров'я. Окрім цього, в окремих контекстах політична коректність інтерпретується як прагнення переважно з боку владних структур приховати, завуалювати негативні чинники в політичній і соціальній сферах.

Категорія політичної коректності знаходить своє вираження на лексичному рівні мови.

Перспективами дослідження явища політичної коректності у сучасному мовному просторі $\epsilon$ характеристика цього явища як культурно-поведінкової категорії мови, грунтовне вивчення його національної специфіки, а також детальний аналіз та класифікація різних форм вираження політичної коректності у мовній картині світу.

\section{АНОТАЦІЯ}

Наукову розвідку присвячено феномену політичної коректності, яка стала невід'ємною частиною міжнародної лінгвокультури і помітно позначилась на розбудові суспільних відносин. Детально розглянуто поняття політкоректності як соціолінгвістичної категорії. З'ясовано причини виникнення політкоректності, іiі функціонування у сучасному мовному просторі. Зазначено, що це питання стає особливо актуальним у складні перехідні періоди, коли відбувається переоцінка традиційної системи цінностей, зазнають трансформації певні соціокультурні 
норми. Наголошено, що поява політкоректності тісно пов'язана 3 виникненням ідеї культурного плюралізму. Особливу роль тут відіграє мовний та культурно-поведінковий аспект. Детально розглянуто найпоширеніші види дискримінації, зокрема статеву, расову, за фізичними вадами і за належністю до сексуальних меншин.

\section{ЛIТЕРАТУРА}

1. Андрейців I. Словничок освіченого українця. Як можна і не можна говорити про людей. Украйнська правда. 2018. URL: https://life.pravda.com.ua/society/2018/01/23/228588/.

2. Бондаренко О., Буткевич М. Мова ворожнечі та ЗМI: міжнародні стандарти та підходи. Київ : Проєкт «Без Кордонів» ГО «Центр «Соціальна Дія», 2015. 64 с.

3. Ионин Л. Общество меньшинств: политкорректность в современном мире. Москва : Издательский дом Государственного университета, 2010. 44 с.

4. Ионин Л. Политкорректность: Дивный новый мир. Москва : ООО «Ад Маргинем Пресс», 2012. 112 с.

5. Карманная энциклопедия The Hutchinson. Москва : Внешсигма, 1995. $750 \mathrm{c}$.

6. Керст I. Олена Малахова: «Фемінітиви - не данина моді, вони властиві українській мові як системі». WOMO. 2018. URL: http://womo.ua/olena-malahova/.

7. Комлев Н. Словарь иностранных слов. Москва : Эксмо, 2006. $672 \mathrm{c}$.

8. Лобанова Л. Новый стиль речи и культура поколения. URL: www.portal-slovo.ru/philology/374Л21.php.

9. Маєрчик М., Малес Л. Гендер для медій. Київ : Критика, 2017. $224 \mathrm{c}$.

10. Никифорович Г. Политическая корректность как точная наука. URL: http:/magazines .russ.ru/ zz/19/nil7.html.

11. Палажченко М. К вопросу о политической корректности, настоящей и мнимой, и политике двойных стандартов. Вестник МГУ. Сер. 19. «Лингвистика и межкультурная коммуникация». 2004. № 1. C. $81-89$.

12. Панин В. Политическая корректность как культурноповеденческая и языковая категория : автореф. дис. на соискание ученой степени канд. филол. наук : спец. 10.02.20 «Сравнительноисторическое, типологическое и сопоставительное языкознание». Тюмень, 2004. 19 с.

13. Сінькевич О. Політкоректність в контексті глобалізаційних процесів сучасності. SWorld. 2013. № 2.12 с. 
14. Собецька Н. Вживання фемінітивів як прояв гендерної культури. Молодий вчений. Тернопіль : Тернопільський національний економічний університет, 2016. С. 375-378.

15. Тер-Минасова С. Язык и межкультурная коммуникация. Москва : Слово, 2000. 264 с.

16. Трофимова 3. Словарь новых слов и значений в английском языке. Москва : Павлин, 1993. 304 с.

17. Шаров К. На темной стороне политкорректности: гендернонейтральный новояз. Вопросы философии. 2010. № 3. С. 30-43.

18. Шляхтина Е. Языковой аспект политкорректности в англоязычной и русской культурах : автореф. дис. на соискание ученой степени канд. филол. наук : спец. 10.02.19 «Теория языка». Ярославль, 2009. $24 \mathrm{c}$.

19. Эко У. О политкорректности. Полный назад / пер. с итал. Москва : Эксмо, 2007. 215 с.

20. Ravitch D. Multiculturalism: E Pluribus Plures. Are You Politically Correct?: Debating America's Cultural Standards. Prometheus Books, Buffalo, N.Y., 1993. P. 165-185.

21. Raymond W. Dictionary of Politics. Brunswick Publishing Co., Lawrenceville, Virginia, 1995.

22. Kołakowska A. Imagine: Intelektualne źródła poprawności politycznej. Wojny kultur $i$ inne wojny. Warszawa : Fundacja Swietego Mikolaja, 2012. 312 p.

\section{Information about the authors:} Koliadych Yu. V., Candidate of Philology Sciences, Senior Teacher at the Chair of Foreign Languages Teaching Methods Vinnytsia Mykhailo Kotsuibynskyi State Pedagogical University 32, Ostrozhskogo str., Vinnytsia, 21100, Ukraine

Khotsianiuska I. V., Candidate of Philology Sciences, Associate Professor at the Chair of the Ukrainian Culture and History Vinnytsia Mykhailo Kotsuibynskyi State Pedagogical University 32, Ostrozhskogo str., Vinnytsia, 21100, Ukraine 